\title{
Revelations of US Financial Crisis for the Financial Development of China
}

\author{
Xiaoling Chou \\ School of Management, Xi' an University of Science and Technology, Xi'an 710054, China \\ E-mail: xaxlchou@yahoo.com.cn
}

\begin{abstract}
The financial crisis of 2008 occurring in US not only largely destroyed the financial system and the macroeconomic system of US, but also directly impacted the economy of China because of the increasing mutual infiltration of global capital market. As viewed from financial regulation and financial innovation, the revelations of the financial crisis for the financial development of China are respectively analyzed in this article.
\end{abstract}

Keywords: Financial crisis, Financial regulation, Financial development

The financial crisis of 2008 occurring in US not only largely destroyed the financial system and the macroeconomic system of US, but also directly impacted the economy of China because of the increasing mutual infiltration of global capital market. As viewed from financial regulation and financial innovation, the revelations of the financial crisis for the financial development of China are respectively analyzed in this article.

\section{Introduction}

In recent years, the economic growth speed of China has been maintained at about $9 \%$, and under the premise that economic gross increases, the financial institution and the financial market of China are in the key stage continually developing and deepening. After the financial crisis of 2008 occurred in US, the revelations and lessons of this crisis offer a good change for the learning and self-examination of the financial development of China.

\section{Revelations for the development of Chinese financial system}

\subsection{Revelations for the financial regulation of China}

In the tide of the global financial liberalization begun in 1980s, the principle that "the financial products should be benefited in public competition, and reduce the governmental interference to the minimum degree" is being advocated. The former chairman of American Federal Reserve, Greenspan specially said that "the self-regulation of financial market is more effective than the governmental regulation". According to thus regulation concept, various governments all loosened the regulation standard.

In 1999, US passed the law of "Financial Service Modernization of US", and allowed that the merchant banking, the mortgage credit, the business of investment bank, and the business of the insurance and asset management were all developed in one subject of enterprise. The expansion of banking operation and the free regulation system quicken the step of financial innovation, and from the following transfer route of financial crisis, the crisis spread very quickly driving by the innovation.

Crisis broke out and the price of relative sub-prime derived products fell, and the assets of institutions such as banks write down and lost, and the public lost confidence to the bank system and make the fluidity to be frozen, and the payment ability of some banks were suspected, and the risk of counterparty increased and the inter-bank market was forced to close, and the large capital and fluidity dried up, the equity financing of third party increased difficultly, and the financing modes of bank decreased quickly, and banks were forced to seek the passive solutions.

The crisis almost made the financial market collapsed, and the crisis also showed that there was not a uniform and optimal financial regulation system in the world, and the financial regulation system of each country must the match with the development of its own financial system, and accord with the stage of opening finance. So the financial regulation of China must enhance the regulation cover from the practice of China, and keep the stable development of the financial system.

With the increase of the integration of various financial markets, it is very important to strengthen the cooperation of international financial regulation. On the one hand, the regulation boundary should be concerned to avoid repeat regulation. On the other hand, the uniformity of the international regulation standard should be strengthened. Different regulation standards will induce the behavior of regulatory arbitrage in the market. The regulation standards about bank, insurance, and securities of China are gradually following the international standards. At present, the financial regulation authority and the monetary policy authority are differentiated in various countries, so except for emphasizing the harmony between China and the monetary policies of other countries, the communication of the financial regulation information and the cooperation between the regulation institution and the central bank are also very important. 


\subsection{Revelations for China to prevent the risk of global financial system}

In recent years, in the falsely flourish feint of real estate of US, the lending institutions loaned moneys under large risks, and pushed many loan products with small monthly repayment and fixed interest in the former stage and floating interest and rising mortgage costs in the later stage, which made some borrowers could not pay the debts in the future. In the securitization of mortgage loan, the investment banks also reduced the consignment or guarantee threshold, and actively extend the risks to wider range in the sale promotion of secondary market. Under the premise with low income level and bad reputation, borrowers bought the house property that they could not assume actually, which induced the present debt crisis. But the speculators of "house traders" played "karate" by means of various circulation credit tools, and once the bubble of real estate broke, they might be changed to "indebted people" from moneybags. The sub-prime crisis made the supply and demand to pay painful costs, and it told us that we should never ignore the existence of risk.

The financial crisis of US reveals that when the finance industry of China actively and stably pushes the opening-up, the risks in the global financial system should not be ignored. One important point is that the financial institutions of Chinese bank industry must be reformed more deeply, and they should improve the ability of risk management and enhance the comprehensive competitive force. At the same time, it is the general trend that Chinese financial enterprises "go to the exterior world", but they can not blindly extend coarsely, and must put the risk management at the first position.

\subsection{Revelations for the prudent management of Chinese financial institutions}

The bank industry was the industry suffering most in the financial crisis of US, and the risk concealed back the home mortgage should be fully concerned by the commercial banks of China. In the stage when the real estate rises, the home mortgage loan is the high quality asset for commercial banks, and the loan return rates are relatively higher, and the rate of violation is lower, and once the violation occurs, the mortgaged real estate can be compensated by inch of candle. At present, the mortgage loan of real estate occupies quit large proportion in the assets of Chinese commercial banks, and it is one main source of loan income. However, once the market price of real estate descends universally and the interest of mortgage loan ascends at the same time, house purchasers' violation rate will ascend largely, and the value of real estate after the auction may be lower than the principal and interest of mortgage loan, even than the principal, which will make the bad debt ratio of commercial banks rise significantly, and impact the profitability and the capital adequacy rate of commercial banks.

In fact, the source of this financial crisis of US is that the financial institutions of US real estate loosened the loan conditions in the flourishing stage of market, and pushed the improper loan product. Before the sub-prime crisis of US occurred, financial institutions reduced the loan standards to pursue profits, and ignored the first payment source of home loan because of continual rise of house price, i.e. the borrowers' payment ability. For the marketing, the loan companies and banks pushed a series of new products including the so-called "loans without down payment and documents", but now, these behaviors are not prudent. Banks securitized these loans and transferred the risk to the capital market form the bank account, but the risk had not disappeared, but planted a curse for the crisis.

Chinese commercial banks should fully emphasized the lesson of US financial crisis, and strictly ensure the execution of the down payment policy, properly enhance the rate of down payment, and stop the occurrence of zero down payment. Banks should also adopt strict credit auditing before loaning and avoid the false mortgage. Therefore, Chinese financial institutions should absorb lessen from this financial crisis and fully recognize the important of prudent management.

\section{Revelations of financial crisis for Chinese financial innovation}

The financial crisis of US shows that the tool of financial innovation could export the management or investment risk of the host country to influence the global capital market. Therefore, in the big background of financial globalization, the financial innovation must insist wide eyeshot and far strategic insight. For long, developed countries such as US have leaded the historical tide of global financial innovation, and various innovational products certainly essentially have changed traditional banking, but the financial innovation also brought continual troubles, especially the financial crisis of US in last year. As viewed from certain angle, this crisis shadowed the financial innovation in the ascendant in the world, but the revelations and lessons in it could help us to make clear the financial innovation of the banking in China.

\subsection{Preparing for the possible market influences of financial innovation}

In the sub-prime crisis of US, the innovational tools such as the derivative products in financial innovation had large execution which had not been known before hand. The sub-prime debt certainly could fulfill the housing requirement of US families with low income to large extent, especially some of these families wanted to benefit from rising house price. Though US bore the large pressure of this financial pressure, but it also successfully exported the financial risks to the world by the mode of financial innovation. Because US imputed the income and risk of the junior bond to the investors in the global capital market by the financial innovation, the investment risk induced by the junior bond was naturally assumed by the whole global capital market. It may be difficult to judge the securitization of house mortgage loan, but one positive point is that the financial innovation decision of Chinese financial institution should not be gave up, or the 
step of financial innovation should not be postponed.

\subsection{The financial innovation of Chinese financial institutions can not be divorced from the national situation of China}

In fact, the financial innovation can not leave the economic and financial environment of one country for ever, for example, the sub-prime debt of US was generated in the special age after 911 . Therefore, in the financial innovation, several basic characters about the change of the national situation of China must be emphasized in certain term.

First, the capital market of China has formed certain scale and gradually gone to the mature state. With the continual expansion and standardization of Chinese stock and fund market, common people continually recognize this new market, and traditional banking certainly faces more and more austere challenges. In the future, even if the development of capital market can not essentially overthrow the monopolization status of traditional loan business, but it will shake the base that the banks mainly depend on the interest difference of deposit and loan.

Second, the income distribution and wealthy structure of urban inhabitants have been changed largely. With the sustainable and high-speed development of Chinese economy in twenty years, the long-term pyramid income structure of Chinese urban residents is being replaced by the olive structure with "two small ends and big middle". In international experiences, with the forming of this olive distribution structure, the investors with different risk favors will gradually grow, and to continually fulfill investors' different investment risk favors is not only a tough task before financial institutions, but the necessary choice to implement the operation transition and enhance the competitive force of the market.

\subsection{Financial institutions should insist the principles of "prudent management" when implementing financial innovation}

The most profound lesson of this financial crisis of US is that the financial innovation can not breach the basic principle of "prudent management".

First, the lever effect of financial innovation should challenge the basic principle of "prudent management" of financial institutions in public. The direct result of the home mortgage loan securitization is that the banks or financial companies will expand the credit scale when they obtain the cash flow again, and the junior loans will not only be formed as various financial products, but be distributed into various investment product combinations of financial institutions, and will be amplified as various trades about the sub-prime debts by the hedge fund and other financial lever tools to tens even hundreds times, and finally relative investment and trading risk will be amplified. At the same time, the association between the value of quite more derivative products and the value of real assets, and the lever effect of financial innovation will not keep away from the principle of "prudent management" of financial institutions, but insulate the market participators out of the hedge of "prudent management".

Second, the after the management risk is transferred to the society, the financial institutions certainly will sacrifice the principle of the "prudent management" to extend the credit scale because of their greedy nature. Once the risks break out, the whole society will be shocked, and it will be too late to give attention to whether the issuance quality of original credit products followed the principle of prudent management. Therefore, the practical issue in the innovation of financial derivative products is that how to effectively link the principle of "prudent management" with the serious lagging of loan behaviors and concealed risks without the limitation of risk.

Third, the financial derivative products kept away from the principle of "prudent management" from the word go. The value of representative derivative product depends on the change of original asset value, but because of financial innovation, after the derivative products are packaged carefully and pushed to the capital market by investment bankers through cutting, packaging, evaluating, pricing, and financial engineering model, their prices and investment values would always been overrated, and the market risk may break out at any time. At the same time, the basic principle of "prudent management" will disappear into thin air. Therefore, the profound less of this financial crisis is that the basic principle of "prudent management" must be insisted very well in the financial innovation. How to effectively deal with the relationship between the innovation and the prudent management may be a long-term and intractable practical problem before us.

\section{References}

Cheng, Jingdong \& Chen, Si. (2007). Market Flourish and Financial Innovation As Viewed from Subprime Crisis. China Finance. No. 19. P.62-63.

Ma, Hongxia \& Sun, Guohua. (2009). Analysis of the Crisis and Transition of US Investment Banks. Studies of International Finance. No. 3.

Wang, Jincheng. (2008). Supervision Self-examination and Lessons of Financial Crisis. China Finance. No. 24. P.24.

Xu, Ming. (2009). Crisis Perspective: Review and Lesson of Classic Economic Crisis in Past Hundred Years. Beijing: Publishing House of Economic Science.

Yin, Mengbo. (2004). Monetary Finance. Beijing: China Finance Press. 